\title{
Stability and activity of TG25P phage in control of Aeromonas hydrophila in striped catfish pond water
}

\author{
Xuan T.T. Tran, Le D. Tam, Hoang A. Hoang*
}

Department of Biotechnology, Faculty of Chemical Engineering, Ho Chi Minh City University of Technology, Vietnam National University - Ho Chi Minh City (VNU-HCM), 268 Ly Thuong Kiet St., District 10, HCMC, Vietnam

\section{Correspondence}

Hoang A. Hoang, Department of Biotechnology, Faculty of Chemical Engineering, Ho Chi Minh City University of Technology, Vietnam National University - Ho Chi Minh City (VNU-HCM), 268 Ly Thuong Kiet St., District 10, HCMC, Vietnam

Email: hoang.a.hoang@hcmut.edu.vn

\section{History}

- Received: 10 July 2018

- Accepted: 30 September 2018

- Published: 06 October 2018

DOI :

https://doi.org/10.32508/stdj.v21i2.429

\section{Check for updates}

\section{Copyright}

(C) VNU-HCM Press. This is an openaccess article distributed under the terms of the Creative Commons Attribution 4.0 International license.

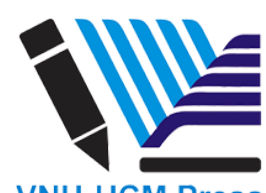

\begin{abstract}
Introduction: Striped catfish (Pangasianodon hypohthalmus) is a native freshwater fish species in the Mekong Delta, Vietnam, and significantly contributes to national aqua exports. Currently, however, the sustainable development of striped catfish farming is being affected by bacterial pathogen infections, of which hemorrhagic septicemia caused by Aeromonas hydrophila bacteria is one of the most common diseases. Methods: In this study, the stability of TG25P and CT45P phages to factors such as temperature, $\mathrm{pH}$, and organic solvents was investigated, with the stability of TG25P being found to be higher than that of CT45P. Results: The activity of TG25P was retained to approximately $90 \%$ and $80 \%$ at $37^{\circ} \mathrm{C}$ and $50^{\circ} \mathrm{C}$ for $1 \mathrm{~h}$, respectively. Its activity was maintained to greater than $80 \%$ at pH 5-9 for $24 \mathrm{~h}$ and approximately $90-100 \%$ in organic solvents, such as chloroform or diethyl ether, for $1 \mathrm{~h}$. In addition, the stability and activity of TG25P for the control of A. hydrophila in striped catfish pond water was also evaluated for $48 \mathrm{~h}$. Conclusion: TG25P was found to be highly applicable in the creation of low-cost phage-containing products for the prospective application of phage therapy in prevention and treatment of hemorrhagic septicemia in striped catfish.

Key words: Antibiotic resistance, Fishpond water, A. hydrophila, Phage stability, Striped catfish
\end{abstract}

\section{INTRODUCTION}

Striped catfish (Pangasianodon hypohthalmus or Vietnamese catfish) is a native freshwater catfish species in the Mekong Delta, Vietnam (MKDVN). Vietnam accounts for $90 \%$ of global striped catfish production ${ }^{1}$. In 2017, the area of striped catfish farms in the MKDVN was 5,822 ha, with a total striped catfish production of 1.3 million tones and an export value of US $\$ 1.8$ billion dollars ${ }^{2}$. However, the annual cycle of bacterial pathogen infections significantly affects the sustainable development of the striped catfish industry in the region. In 2012, and for the striped catfish segment alone, an area of 2,402 ha was infected with pathogens (http://forum.pangasiusmap .com/threads/quan-ly-dich-benh-tren-ca-tra.3), with one of the most common types being hemorrhagic septicemia caused by $A$. hydrophila.

Usage of antibiotics as a measure for prevention and treatment of hemorrhagic septicemia disease has been commonly used in the region. However, the practice has not been appropriately administered and controlled, which has led to undesirable effects and consequences threatening not only striped catfish industry growth but social and economic development in the region. Inadequate control of antibiotic resistance of A. hydrophila on striped catfish farms has also been a significant problem. Quach et al. (2014) demonstrated a high ratio of antibiotic resistance of $A$. $h y$ drophila isolates in ill striped catfish in the MKDVN, such as $100 \%$ for ampicillin, amoxicillin, cephalexin, and trimethoprim/sulfamethoxazole, and $93 \%$ for tetracycline ${ }^{3}$. Moreover, higher-than-approved-limit antibiotic residuals have also been detected in exported stocks. Thus, many consignments have been rejected by importing markets, such as the US, Russia, Japan, South Korea and Canada. In addition, improper usage of antibiotics can negatively affect the farming biological environment over time.

Due to these adverse impacts, there is an urgent need to develop alternative therapies to antibiotics on fish farms. Bacteriophages (or phages) are viruses which infect only bacteria. They were first discovered by Frederick W. Twort ${ }^{4}$. Phage therapy involves the therapeutic use of phages to prevent and treat pathogenic bacterial infections. This therapy has only gained serious attention in the aqua industry in the last 30 years due to the wide spread of antibiotic resistance in bacteria. Phage therapy has shown its efficacy in treatment of bacterial diseases in fish and shellfish (reviewed by Richards, 2014; Doss, 2017 ${ }^{5,6}$ ).

In our previous study, some phages to control $A$. hydrophila in stripped catfish were isolated and selected based on latent period, burst size, host receptor, 
etc. $^{7}$. Two phages (TG25P and CT45P) were demonstrated to have short latent periods (40 and $25 \mathrm{~min}$, respectively), high burst size (79 \pm 11.9 and $67 \pm$ $1.4 \mathrm{PFU} /$ cell, respectively), and different host receptors for infection initiation. These phages may be promising for phage therapy to control A. hydrophila infection in striped catfish. However, phages are constructed relatively simply with a protein capsid and nucleic genome. Their activity is significantly affected by preservation and environmental conditions. Thus, phage stability should be clarified prior to in vivo trials.

In this study, the stability of TG25P and CT45P with respect to temperature, $\mathrm{pH}$, and organic solvents was investigated. Furthermore, the stability and activity of TG25P in control of A. hydrophila in striped catfish pond water were also evaluated.

\section{METHODS}

\section{Temperature stability test}

Phage stocks of TG25P and CT45P were prepared against $A$. hydrophila strain $\mathrm{A1}^{8}$. The stability of each phage at various temperatures $(4,20,25,30,37$, and $\left.50{ }^{\circ} \mathrm{C}\right)$ was investigated by incubating the phage $\left(\sim 10^{9}\right.$ $\left.\mathrm{PFU} \mathrm{mL}{ }^{-1}\right)$ at the respective temperatures for $1 \mathrm{~h}^{9-11}$. Sampling was conducted every $10 \mathrm{~min}$, and the phage titer was estimated by serial dilution and the double agar-layer method ${ }^{7}$. The experiment was conducted in triplicate.

\section{pH stability test}

To determine the stability of the phages at various $\mathrm{pHs}$, the $\mathrm{pH}$ of tryptone soya broth (TSB) was adjusted using either $1 \mathrm{M} \mathrm{HCl}$ or $1 \mathrm{M} \mathrm{NaOH}$ to attain solutions with pHs of $3,4,5,6,7,8,9,10$ and 11. Each phage suspension $\left(\sim 10^{9} \mathrm{PFU} \mathrm{mL}{ }^{-1}\right)$ was mixed with an equal volume of the TSB and incubated at $30^{\circ} \mathrm{C}$ for $24 \mathrm{~h}^{9-11}$. After incubation, the phage titer was estimated by serial dilution and the double agar-layer method, as described above. Phage suspension maintained at $\mathrm{pH} 7$ was used as control. The experiment was conducted in triplicate.

\section{Organic solvent stability test}

To assess the stability of the phages in organic solvents, a volume of each phage $\left(\sim 10^{9} \mathrm{PFU} \mathrm{mL}^{-1}\right)$ was mixed with an equal volume of appropriate organic solvent (ethanol, chloroform, diethyl ether, SM buffer) and incubated at $30^{\circ} \mathrm{C}$ for $1 \mathrm{~h}^{9,10}$. The mixture was then centrifuged at $4^{\circ} \mathrm{C}, 10,000 \times \mathrm{g}$ for $10 \mathrm{~min}$. Phage titer was estimated by serial dilution and the double agar-layer method, as described previously. Phage suspension mixed with Phosphate Buffered Saline (PBS) was used as control. The experiment was conducted in triplicate.

\section{Challenge test in pond water}

Inactivation of A. hydrophila A1 cells in a striped catfish pond water sample by TG25P phage was examined. The bacterial culture was shaken at $30^{\circ} \mathrm{C}, 120$ $\mathrm{rpm}$ in TSB until its $\mathrm{OD}_{600}$ of $0.1\left(\sim 10^{7} \mathrm{CFU} \mathrm{mL}^{-1}\right)$ was achieved. The culture was centrifuged at 10,000 $\times \mathrm{g}, 4^{\circ} \mathrm{C}, 5 \mathrm{~min}$ to obtain a pellet. The pellet was suspended in the same volume of sterilized pond water. The centrifugation and suspension were repeated to discard residuals of TSB. The final pellet was suspended and serially diluted in sterilized pond water to obtain a bacterial concentration of $\sim 10^{5} \mathrm{CFU}$ $\mathrm{mL}^{-1}$. The solution was divided into two aliquots in Erlenmeyer flasks, with one aliquot being mixed with TG25P phage lysate at a multiplicity of infection (MOI) of 50 (phage : host), and the other aliquot left blank without phage addition. The mixtures were shaken at $30^{\circ} \mathrm{C}, 40 \mathrm{rpm}$. Sampling was performed at $0.5,1,2,3,4,6,8,10,12, \ldots$ and $48 \mathrm{~h}$. In case of the mixture of host bacteria and phage, each sample was divided into two aliquots. One aliquot was serially diluted and spread onto Trypticase Soy Agar (TSA) to estimate bacterial concentration. To the other aliquot, a drop of chloroform was added, incubated for $2 \mathrm{~h}$, and centrifuged at $10,000 \times \mathrm{g}, 4^{\circ} \mathrm{C}, 5 \mathrm{~min}$. The phage titer was estimated by serial dilution and the double agar-layer method, as described above. In case of no phage addition, the sample was serially diluted and spread onto TSA to estimate bacterial concentration. Another control was similarly prepared by adding the phage into sterilized pond water. The phage titer was estimated by serial dilution and the double agar-layer method, as described previously. The experiment was conducted in triplicate.

\section{RESULTS}

\section{Thermal and pH stability of phages}

Thermal and $\mathrm{pH}$ stability of phages were evaluated. TG25P was found to be relatively thermostable at 20$37^{\circ} \mathrm{C}$ (Figure 1), with phage activity being retained to approximately $90-95 \%$ compared to control. Activity of TG25P was still retained to about $80-85 \%$ of the control at the relatively high temperature of $50^{\circ} \mathrm{C}$. In the case of CT45P, phage activity was relatively similar to that of TG25P at 20,30 , and $37^{\circ} \mathrm{C}$. The phage activity of CT45P was approximately 80 and $75 \%$ at 25 and $50{ }^{\circ} \mathrm{C}$, respectively. The thermal stability of 
these two phages was much greater than other published phages. Jun et al. (2013) investigated thermal stability of phages against mass mortality of the cyprinid loach (Misgurnus anguillicaudatus) caused by $A$. hydrophila and showed that reduction of their activity was approximately 65 to $79 \%$ at $37^{\circ} \mathrm{C}$, and about $95-98 \%$ at $50^{\circ} \mathrm{C}^{10}$. Yamaki et al. (2014) also evaluated the thermal stability of a Morganella morganii phage isolated from river water and revealed that about $90 \%$ phage activity was lost after $1 \mathrm{~h}$ at $50^{\circ} \mathrm{C}$. Overall, both TG25P and CT45P were thermostable at $20-37^{\circ} \mathrm{C}$, with TG25P being relatively more stable than CT45 $\mathrm{P}^{11}$.

A pH stability analysis showed that both phages were stable at $\mathrm{pH}$ 5-9, with relatively little difference in the phage titers with respect to control (Figure 2). In contrast, a significant reduction of phage activity was noted at strong acidic (lower than $\mathrm{pH} 4$ ) and alkaline (higher than $\mathrm{pH} 10$ ) levels. Both phages presented similar infection capabilities at a $\mathrm{pH}$ range of 6-11. CT45P was revealed to be more $\mathrm{pH}$-sensitive than TG25P at $\mathrm{pH} 4-5$. These two phages were more stable in terms of $\mathrm{pH}$ than other published phages ${ }^{10,11}$.

\section{Organic solvent stability of phage}

No effect on phage activity of TG25P was observed after $1 \mathrm{~h}$ of incubation with either chloroform or SM (Figure 3). The phage activity was retained to about $65 \%$ and $85 \%$ after incubation with ethanol or diethyl ether, respectively. TG25P showed high resistance to organic solvents, particularly to ethanol, whereas many other published phages completely lost their activity after treatment with ethanol ${ }^{9,10}$. Figure 3 also demonstrated that TG25P was more resistant to ethanol, chloroform, and diethyl ether than CT45P. Therefore, TG25P was found to be relatively more stable than CT45P in terms of temperature, $\mathrm{pH}$, and organic solvents. This phage was selected to examine its stability and activity in control of $A$. hydrophila in a striped catfish pond water sample.

\section{Inactivation of $A$. hydrophila in pond water by phage}

Initial host cells at $\sim 10^{5} \mathrm{CFU} \mathrm{\textrm {mL } ^ { - 1 }}$ were added into sterilized striped catfish pond water. Figure $4 \mathrm{~A}$ shows a time course of host cells during the experiment. At the first $2 \mathrm{~h}$ of incubation, an increase of host bacterial count was seen for both experiments (with or without phages). However, host bacterial count in the challenge with TG25P sharply decreased in the next $4 \mathrm{~h}$ of incubation. This trend was maintained for 8 $\mathrm{h}$ of challenge. In contrast, viable bacterial count in the negative control (host cells without phages) maintained the increased trend during the next $8 \mathrm{~h}$ and was maintained as stable for $48 \mathrm{~h}$. At $8 \mathrm{~h}$, viable bacterial count of the control was approximately 8.0 log compared to about $5.0 \log$ of the challenge with phages. This result indicated a high-efficient inactivation of $A$. hydrophila in pond water by TG25P when most of the host cells were infected and lysed by phages, resulting in the sharp decrease of bacterial count in the solution. After $8 \mathrm{~h}$, viable bacterial count in the bacterium-phage solution re-increased, indicating growth of phage-resistant bacterial strains. The host cell count was still approximately 1.0 log lower for the bacterium-phage solution than that of the control. Figure 4B shows a time course of TG25P phage during the experiment. Together with lysing host cells, phage particles were also newly generated. Phage titer slightly increased during the first $16 \mathrm{~h}$ and then sharply increased to $7.5 \log$ until $26 \mathrm{~h}$. The phage titer was then stably maintained. In the control (phage without host cells), phage titer was almost stable during $48 \mathrm{~h}$, indicating the stability of TG25P in striped catfish pond water.

\section{DISCUSSION}

A. hydrophila is one of the main causative agents of mass mortality in striped catfish in the MKDVN. However, no effective method has been applied to control A. hydrophila infection, except for the usage of antibiotics. A high resistance rate of $A$. hydrophila to antibiotics has resulted in a significant loss in production output. Furthermore, antibiotic residuals at higher-than-approved limits have also been detected in exported stocks. The United States is the biggest market for export of Vietnamese striped catfish. However, from August $2^{\text {nd }}, 2017,100 \%$ of consignments of imported striped catfish have been tested for residuals of 89 types of antibiotics by the FDA (2017) ${ }^{12}$. Many consignments to leading Vietnamese export countries, such as the US, Japan, South Korea, Canada and Russia, have been rejected due to such antibiotic residuals in the products. Therefore, phage therapy is expected to be an effective solution to replacing antibiotic usage on fish farms in the region since it has shown a high efficacy in treating bacterial diseases in many types of fish and shellfish ${ }^{5,6,13}$. However, to the best of our knowledge, relatively little information regarding phage therapy in the treatment of hemorrhagic septicemia in striped catfish has been reported.

Some of the first phages isolated from catfish farms in the MKDVN against A. hydrophila were shown in our prospective paper ${ }^{8}$. The first trial of phage therapy to 


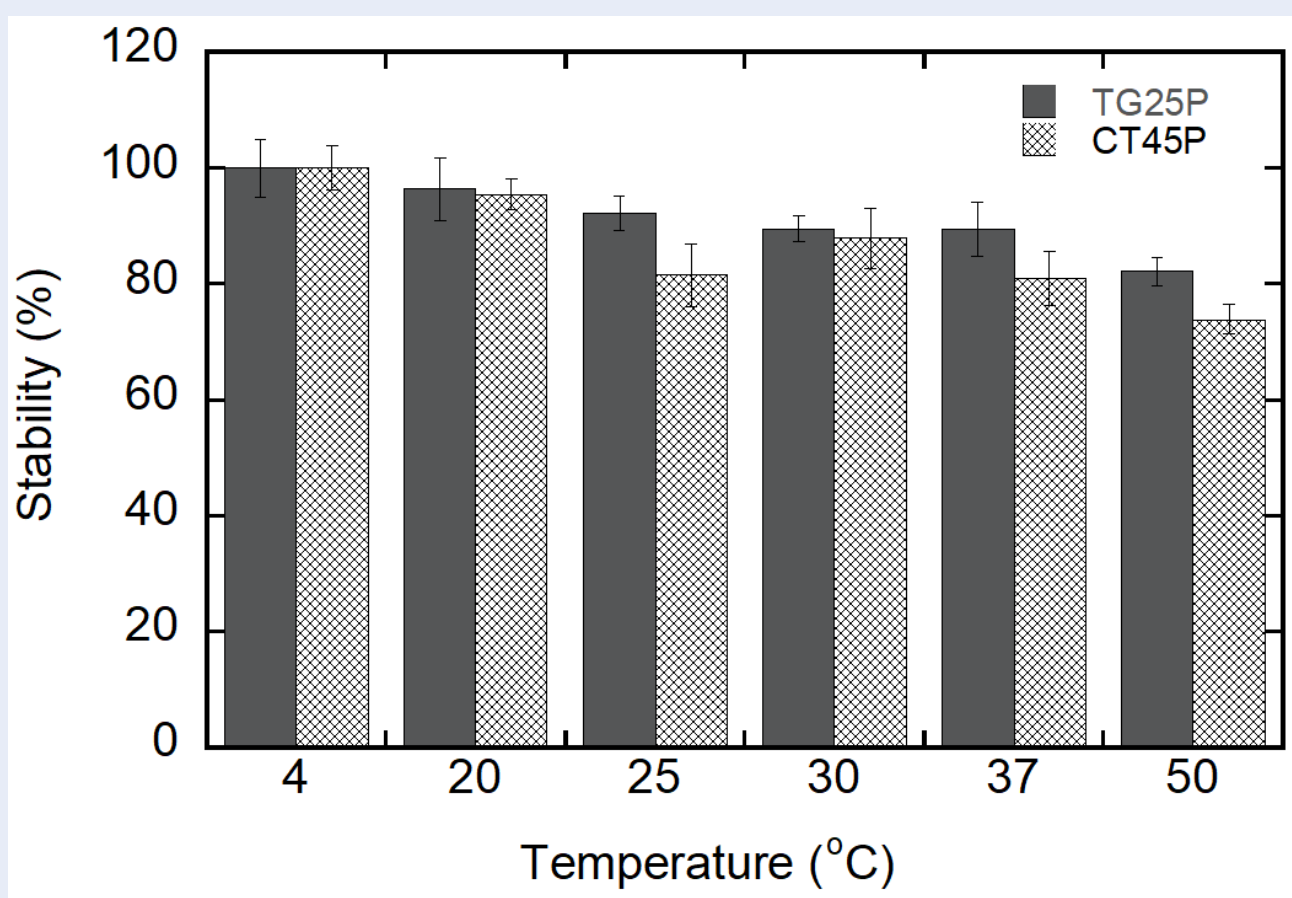

Figure 1: Effect of thermal treatment on the viability of TG25P and CT45P. Optimal condition at $4{ }^{\circ} \mathrm{C}$ was used as control. Error bars indicate $95 \%$ confidence intervals for the averaged values $(n=3)$.

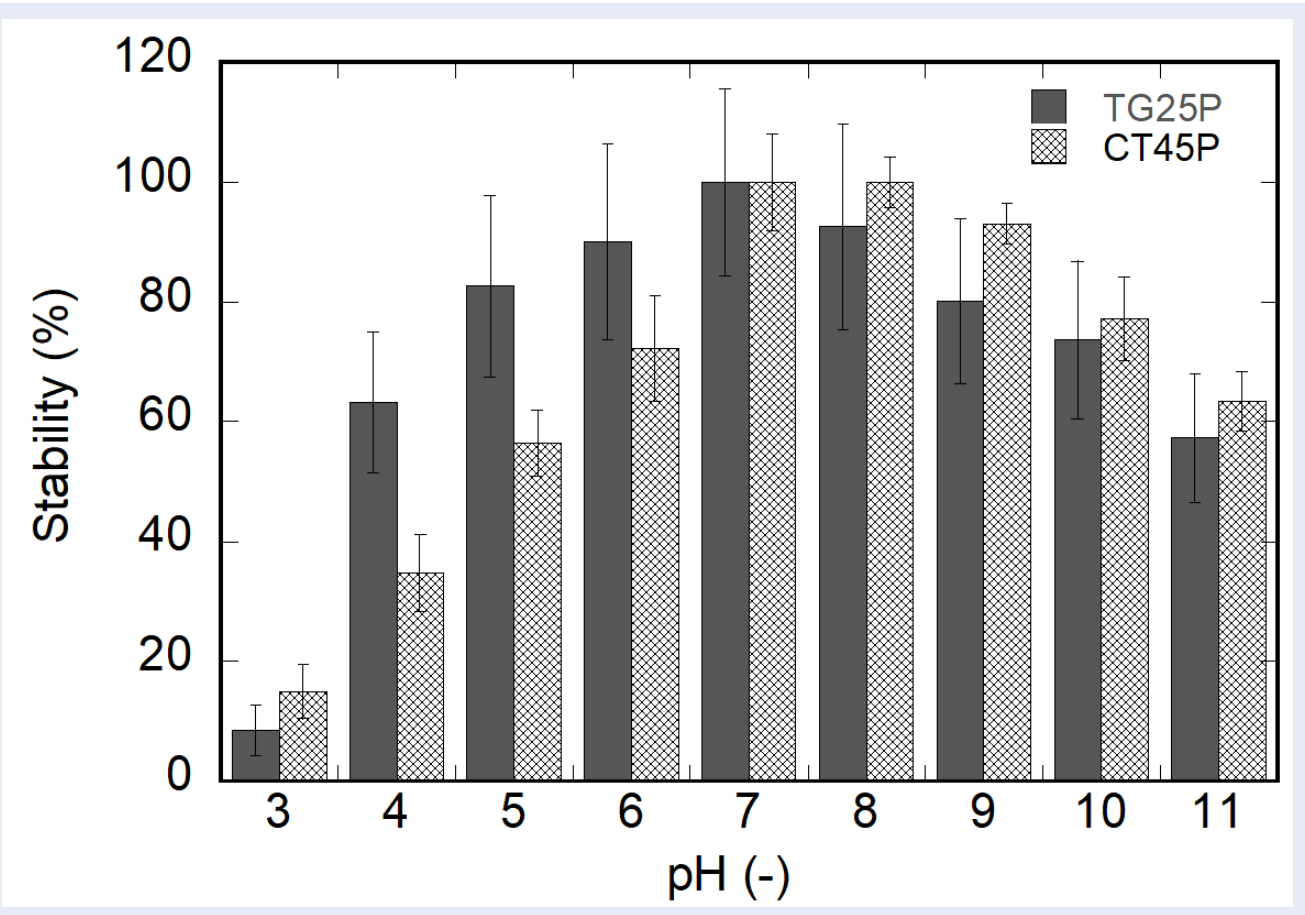

Figure 2: Stability of TG25P andCT45P incubated at various pHs. Optimal condition at pH 7 was used as control. Error bars indicate $95 \%$ confidence intervals for the averaged values $(n=3)$. 


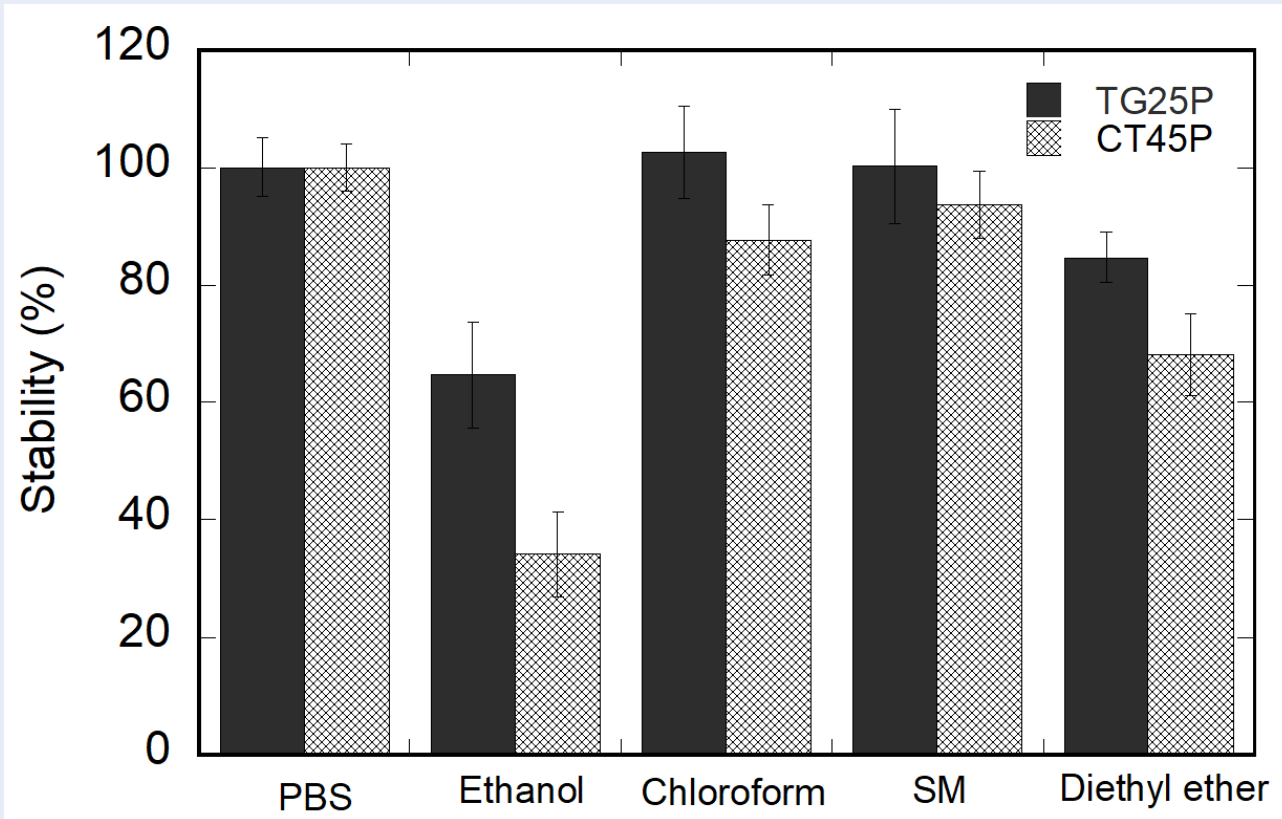

Figure 3: Viability of TG25P and CT45P in the presence of various organic solvents. Incubation of phage in sterile PBS was used as control. Error bars indicate $95 \%$ confidence intervals for the averaged values $(n=3)$.

treat A. hydrophila in striped catfish at a laboratory scale was described by Le et al. (2018) ${ }^{14}$. The study preliminarily described efficiency of phage therapy to treat A. hydrophila infection in striped catfish. However, the approach of the research had two limitations. First, phages were isolated from Saigon River in Ho Chi Minh City, where no farms of striped catfish were available. Second, the manner of injection of $A$. $h y$ drophila and phage into striped catfish were not realizable at farm scale. To solve both limitations, phagecontaining liquid or solid product should be investigated. To apply the phage-containing products at the farm scale, preservation condition of the products should be determined. Preservation of phages has been discussed previously. Generally, most phages maintain their stability when stored at low or freezing temperatures, such as $4,-20$, or $-70^{\circ} \mathrm{C}$. Most research concerned phage preservation in dry or liquid buffer state for usage in the laboratory or medicine ${ }^{15}$.

However, phage preservation at ambient temperature is always challenging when the phage concentration decreases sharply in a period of days ${ }^{16}$. In the current study, TG25P was found to be quite thermostable, with its activity being maintained to approximately $90 \%$ at $37^{\circ} \mathrm{C}$. In addition, cryopreservatives also significantly support survival of phages ${ }^{17}$. TG25P showed a high resistance to organic solvents, such as chloroform, ethanol, and diethyl ether. These organic solvents will protect phage-containing products from contamination of microorganisms. Therefore, TG25P is highly promising in the creation of low-cost phage-containing products stored at ambient temperature.

Striped catfish is relatively vulnerable to pond water conditions, with temperature and $\mathrm{pH}$ being two of the most important parameters. Temperature and $\mathrm{pH}$ ranges in pond water suitable for striped catfish are $25-32{ }^{\circ} \mathrm{C}^{18}$ and $5.5-9.0^{19}$, respectively. As investigated in the current study, activity of TG25P was maintained at greater than $80 \%$ at this temperature and $\mathrm{pH}$ ranges. Therefore, this phage represents a highly appropriate antimicrobial agent against $A$. hydrophila on striped catfish farms.

In this study, TG25P also presented a stable phage titer in pond water for $48 \mathrm{~h}$. It showed a high capacity to inactivate growth of $A$. hydrophila in pond water. The study also indicated growth of phageresistant bacterial strains after 8-h exposure to TG25P phage. The regular emergence of phage-resistant bacteria is one of the major challenges of phage therapy $^{20-22}$. An effective way to tackle the problem is to apply a phage cocktail (a mixture of different phages showing different types of host bacterial receptors) to inactivate phage-resistant bacteria ${ }^{5,13,23}$. In the future studies, CT45P will be examined in phage cocktails 
(A)

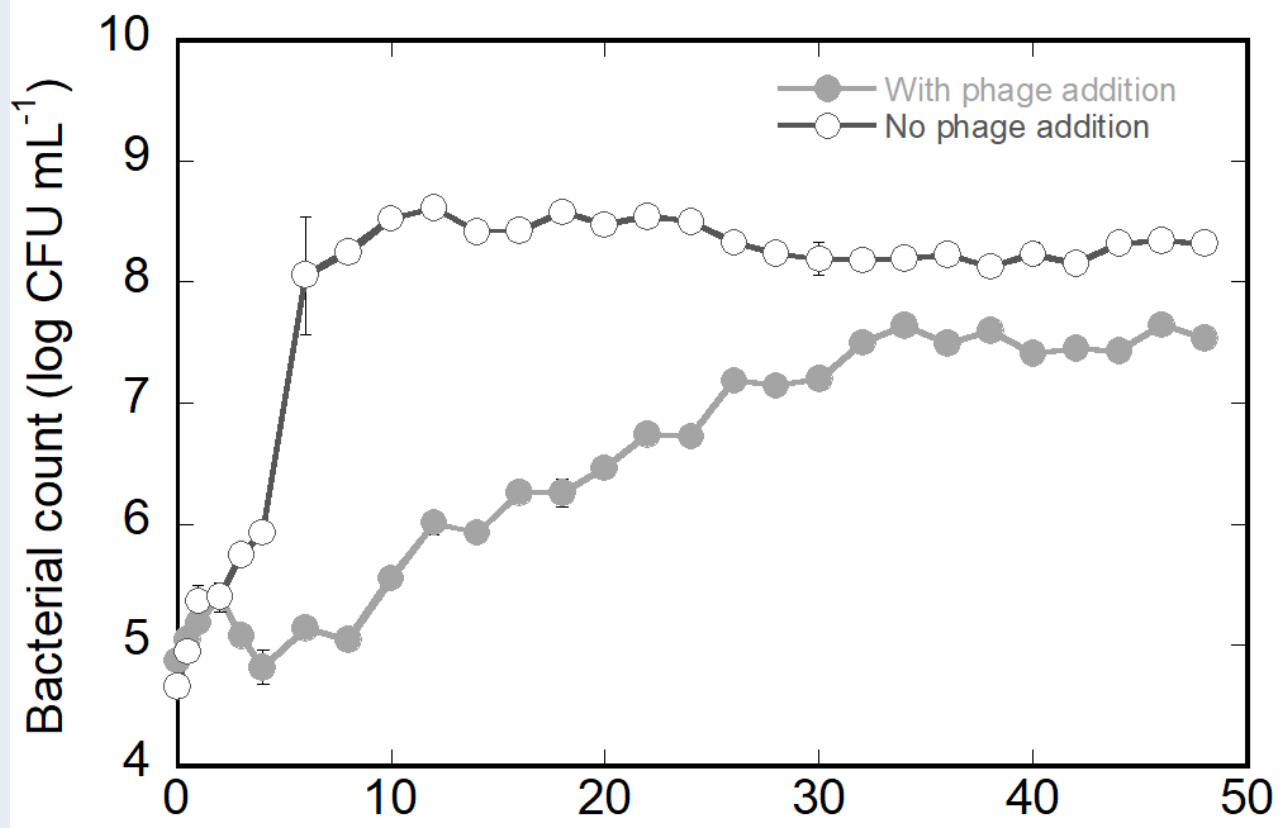

(B)

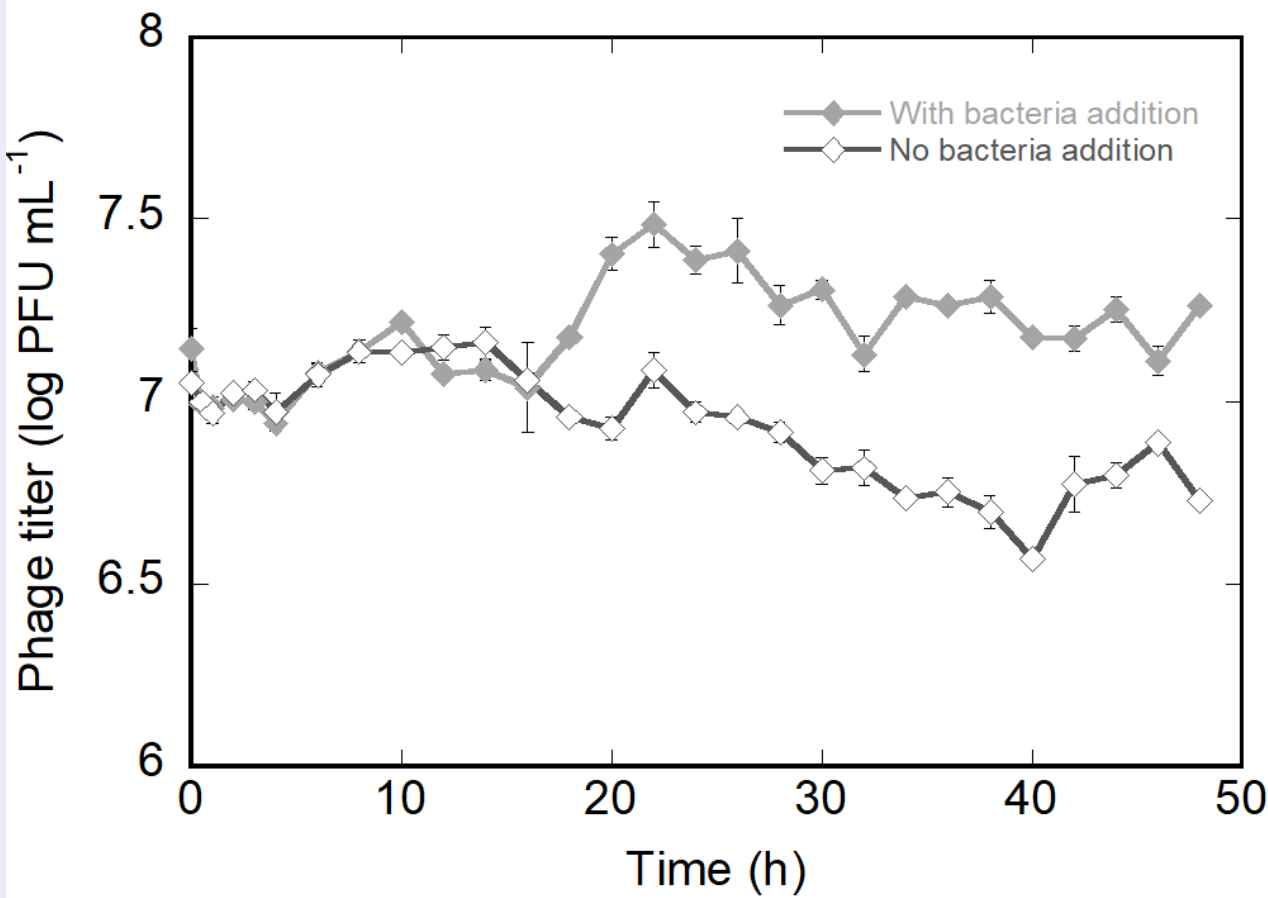

Figure 4: Time course of host cells and phages during the challenge test in striped catfish pond water at $30^{\circ}$ C. (A) Bacterial cell count of A. hydrophila in a mixture with TG25P (closed circle) and without phage - negative control (open circle). (B) Phage titer in the mixture with (closed diamond) and without host cells-negative control (open diamond). Error bars indicating $95 \%$ confidence intervals for the averaged values $(n=3)$ are not graphically detectable as the intervals were too narrow. 
with TG25P since CT45P is also quite stable to ambient temperatures and various $\mathrm{pHs}$, the two phages show different host receptors for infection initiation ${ }^{8}$. In addition, studies on fixation of phages of fish feed will be also conducted toward application of phage therapy on real striped catfish farms.

\section{CONCLUSIONS}

In this study, activity of TG25P phage was demonstrated to be quite stable to different temperatures, pHs and organic solvents such as chloroform, ethanol, and diethyl ether. In addition, it presented a high capacity to inactivate growth of $A$. hydrophila and a stable phage titer in pond water for $48 \mathrm{~h}$. Recently, the sustainable development of striped catfish farming in the Mekong Delta, Vietnam is being affected by hemorrhagic septicemia disease caused by Aeromonas hydrophila. Therefore, TG25P was found to be highly applicable in creation of low-cost phage-containing products for prospective application of phage therapy in prevention and treatment of hemorrhagic septicemia in striped catfish in the region.

\section{COMPETING INTERESTS}

No conflict of interest declared.

\section{AUTHORS' CONTRIBUTIONS}

Xuan T.T. Tran implemented the experiment of inactivation of $A$. hydrophila in pond water by phage. Le D. Tam evaluated stability of phage. Hoang A. Hoang proposed the experimental plan and wrote the manuscript.

\section{ACKNOWLEDGMENTS}

This research is funded by Vietnam National Foundation for Science and Technology Development (NAFOSTED) under grant number 106-NN.042015.30; and International Foundation of Science (IFS, Sweden) under grant number I-2-A-5847-2.

\section{REFERENCES}

1. De-Silva SS, Phuong NT. Striped catfish farming in the Mekong Delta, Vietnam: a tumultuous path to a global success. Reviews in Aquaculture. 2011;3:45-73. Available from: DOI: 10.1111/j.1753-5131.2011.01046.x.

2. Website. Vietnam GS (in Vietnamese); 2017. Available from: https://www.gso.gov.vn/default.aspx?tabid=629\&idmid= \&ItemID $=18316$

3. Quach VC, Tu TD, Dang PH. The current status antimicrobial resistance in Edwardsiella ictaluri and Aeromonas hydrophila cause disease on the striped catfish farmed in the Mekong Delta. J. Sci. - Can Tho University. Aquaculture (Amsterdam, Netherlands). 2014;2:7-14.

4. Twort FW. An investigation on the nature of ultra-microscopic viruses. Lancet. 1915;186:1241-3. Available from: Doi:10. 1016/s0140-6736(01)20383-3.

5. Richards GP. Bacteriophage remediation of bacterial pathogens in aquaculture: a review of the technology. Bacteriophage. 2014;4:e975540. Available from: Doi:10.4161/ 21597081.2014.975540.
6. Doss J, Culbertson K, Hahn D, Camacho J, Barekzi N. A Review of Phage Therapy against Bacterial Pathogens of Aquatic and Terrestrial Organisms. Viruses. 2017;9:50. Available from: DOI: 10.3390/v9030050

7. Hoang HA, Abe M, Nakasaki K. A novel colorimetric method for the detection of Escherichia coli using cytochrome $c$ peroxidase-encoding bacteriophage. FEMS Microbiology Letters. 2014;352:97-103. Available from: Doi:10.1111/15746968.12382.

8. Hoang HA, Tran TTX, Le PN, Dang THO. Selection of phages to control Aeromonas hydrophila - an infectious agent in striped catfish. Biocontrol Sci . 2019;accepted on June 30, 2018:In press.

9. Verma V, Harjai K, Chhibber S. Characterization of a T7-like lytic bacteriophage of Klebsiella pneumoniae B5055: a potential therapeutic agent. Current Microbiology. 2009;59:274-81. Available from: DOI:10.1007/s00284-009-9430-y.

10. Jun JW, Kim JH, Shin SP, Han JE, Chai JY, Park SC. Protective effects of the Aeromonas phages pAh1-C and pAh6-C against mass mortality of the cyprinid loach (Misgurnus anguillicaudatus) caused by Aeromonas hydrophila. Aquaculture (Amsterdam, Netherlands). 2013;416-417:289-95. Available from: DOI:10.1016/j.aquaculture.2013.09.045.

11. Yamaki S, Omachi T, Kawai Y, Yamazaki K. Characterization of a novel Morganella morganii bacteriophage FSP1 isolated from river water. FEMS Microbiology Letters. 2014;359:16672. Available from: Doi:10.1111/1574-6968.12560.

12. FDA. Inspection Program For Siluriformes Fish, Including Catfish; 2017. Available from: https://www.fsis.usda.gov/wps/ portal/fsis/topics/inspection/siluriformes.

13. Defoirdt $T$, Sorgeloos $P$, Bossier P. Alternatives to antibiotics for the control of bacterial disease in aquaculture. Current Opinion in Microbiology. 2011;14:251-8. Available from: DOI: 10.1016/j.mib.2011.03.004.

14. Le TS, Nguyen TH, Vo HP, Doan VC, Nguyen HL, Tran MT. Protective Effects of Bacteriophages against Aeromonas hydrophila Species Causing Motile Aeromonas Septicemia (MAS) in Striped Catfish. Antibiotics (Basel, Switzerland) 2018;7:16. Available from: DOI:10.3390/antibiotics7010016.

15. Choiska-Pulit A, Mitua P, Liwka P, Aba W, Skaradziska A. Bacteriophage encapsulation: trends and potential applications. Trends in Food Science \& Technology. 2015;45:212-21. Available from: DOI:10.1016/j.tifs.2015.07.001.

16. Jończyk E, Kłak M, Międzybrodzki R, Górski A. The influence of external factors on bacteriophages-review. Folia Microbiologica. 2011;56:191-200. Available from: DOI:10.1007/ s12223-011-0039-8.

17. Ackermann HW, Tremblay D, Moineau S. Long-term bacteriophage preservation. WFCC Newsletter. 2004;38:35-40.

18. Duong NL. Techniques for feeding freshwater fishes; 2004.

19. Le HN, Nguyen VB, Nguyen VC. Survey on water quality at industrial Pangasius fish raising areas for fishpond management purposes. Tạp chí Đại học Thủ Dầu Một. 2017;4:46-54

20. Labrie SJ, Samson JE, Moineau S. Bacteriophage resistance mechanisms. Nature Reviews Microbiology. 2010;8:317-27. Available from: DOI:10.1038/nrmicro2315.

21. Oliveira J, Castilho F, Cunha A, Pereira MJ. Bacteriophage therapy as a bacterial control strategy in aquaculture. Aquaculture International. 2012;20:879-910. Available from: DOI: 10.1007/s10499-012-9515-7.

22. Mateus L, Costa L, Silva YJ, Pereira C, Cunha A, Almeida A. Efficiency of phage cocktail in the inactivation of Vibrio in aquaculture. Aquaculture (Amsterdam, Netherlands). 2014;424:167-73. Available from: DOI:10.1016/j.aquaculture. 2014.01.001.

23. Tanji $Y$, Shimada T, Yoichi M, Miyanaga K, Hori K, Unno $H$. Toward rational control of Escherichia coli $0157: \mathrm{H} 7$ by a phage cocktail. Applied Microbiology and Biotechnology. 2004;64:270-4. Available from: DOI:10.1007/s00253-0031438-9. 